\title{
Transactions of the Royal Asiatic Society of Great Britain and Ireland
}

http://journals.cambridge.org/TRA

Additional services for Transactions of the Royal Asiatic Society of Great Britain and Ireland:

Email alerts: Click here

Subscriptions: $\underline{\text { Click here }}$

Commercial reprints: $\underline{\text { Click here }}$

Terms of use : $\underline{\text { Click here }}$

\section{Some Account of a Secret Association in China, entitled the Triad Society}

\section{Milne}

Transactions of the Royal Asiatic Society of Great Britain and Ireland / Volume 1 / January 1827, pp 240 250

DOI: 10.1017/S0950473700000197, Published online: 24 September 2009

Link to this article: http://journals.cambridge.org/abstract_S0950473700000197

How to cite this article:

Milne (1827). XIV. Some Account of a Secret Association in China, entitled the Triad Society. Transactions of the Royal Asiatic Society of Great Britain and Ireland, 1, pp 240-250 doi:10.1017/S0950473700000197

Request Permissions : $\underline{\text { Click here }}$ 
XIV. Some Account of a SECRET Association in ChINA, entilled the Triad Society. By the late Dr. MILNE, Principal of the Anglo-Chinese College. Communicated by the REv. RobERT MorRISON, D.D., F.R.S., M.R.A.S.

Read February 5, 1825.

THE writer of this paper is fully sensible how difficult it is to discover that which is studiously concealed, under the sanction of oaths, curses, and the (supposed) impending vengeance of the gods; and how liable one is, even after the utmost care, to be mistaken in tracing the progress of any set of principles and schemes, which the fortunes or lives of the parties who have adopted them are concerned to hide, to varnish, to distort, and to misrepresent. He therefore offers the following remarks, not as the result of firm and unhesitating conviction, but as having a good deal of probability to support them, and as containing the substance of the best information procurable in his situation. He begs then to say a few words on the name, objects, government, initiatory ceremonies, secret signs, and seal of the said association, and to conclude with a few miscellaneous remarks.

\section{First, the Name.}

The name is not expressed on the seal, and hence it is difficult to ascer. tain it with certainty. It seems, however, to be the * San hr hrouy, i. e. "The Society of the Three united, or the Triad Society." The three referred to in this name are $+T$ 'heen, $t e$, jin, i. e. "Heaven, Earth, and Man," which are the three great powers in nature, according to the Chinese doctrine of the universe. In the earlier part of the reign of his late Chinese majesty, $\ddagger$ Kea King, the same society existed, but under a different denomination. It was then called the $\subseteq$ Theen te hrouy, i. e. "The Colesto-terrestrial Society," or " The Society that unites Heaven and Earth." It spread itself rapidly through the provinces, had nearly upset the government, and

* For the Chinese characters, see Plate I, No. 1. 
its machinations were not entirely defeated till about the eighth year of the said Emperor's reign, when the chiefs were seized and put to death; and it was (in the usual bombast of Chinese reports) officially stated to his majesty, " that there was not so much as one member of that rebellious fraternity left under the wide extent of the heavens." The fact, however, was just the contrary, for they still existed, and operated, though more secretly; and it is said, that a few years after they assumed the name of the "Triad Society," in order to cover their purposes. But the name, by which they chiefly distinguish themselves, is * Hung kea, i. e. the "Flood Family."

There are other associations formed both in China and in the Chinese colonies that are settled abroad, as the $+T$ "heen how hrouy, i.e. the "Queen of Heaven’s Company, or Society ;" called also, the $\ddagger$ Neang ma hrouy, or "Her Ladyship's Society ;" meaning the "queen of heaven, the mother and nurse of all things." These associations are rather for commercial and idolatrous purposes, than for the overthrow of social order; though it is said, that the members of the "Queen of Heaven's Society," settled in Bengal and other parts, unite in house-breaking, \&c:

\section{Secondly, Object.}

The object of this society at first does not appear to have been peculiarly hurtful ; but, as numbers increased, the object degenerated from mere mutual assistance, to theft, robbery, the overthrow of regular government, and an aim at political power. In foreign colonies, the objects of this association are plunder, and mutual defence. The idle, gambling, opium-smoking Chinese (particularly of the lower classes), frequently belong to this fraternity. What they obtain by theft or plunder is divided in shares, according to the rank which the members hold in the society. They engage to defend each other against attacks from police officers; to hide each others crimes; to assist detected members to make their escape from the hands of justice. A Chinese tailor in Malacca, named Tsaou foo, who committed murder, in the close of 1818, shortly after the transfer of the colony, and made his escape from the hands of justice, was a chief man in this society ; and, it is believed, had a considerable number of persons under his direction, both on

\footnotetext{
* See plate, No. 5. † See plate, No. 6. $\quad \ddagger$ See plate, No.7.
} 
the land and at sea. There cannot be a doubt but his escape was partly owing to the assistance of his fellow-members, as a rigorous search was made for him by the police. - In places where most of the members are young, if one takes a dislike to any man who is not a member, the others are sure to mark that man as the butt of their scorn and ridicule. If any one feels injured, the others take part in his quarrels, and assist him in seeking revenge. Where their party is very strong, persons are glad to give them sums of money annually, that they may spare their property, or protect it from other banditti, which they uniformly do when confided in, and will speedily recover stolen goods. In such places as Java, Sincapore, Malacca, and Penang, when a Chinese stranger arrives to reside for any length of time, he is generally glad to give a trifle of money to this brotherhood to be freed from their annoyance.

The professed design, however, of the San ho hrouy is benevolence, as the following motto will shew :

* Yew füh tung heang

Yew ho tung tang.

The blessing, reciprocally share;

The woe, reciprocally bear.

They assist each other, in whatever country, whenever they can make themselves known to each other by the signs.

\section{Thirdly, Government.}

The government (if it be proper to dignify the management of so worth. less a combination by such an epithet) of the San-hŏ.hrouy, is vested in three persons, who are all denominated $+K o$, " Elder brothers," a name given by way of courtesy to friends; in the same manner as Free-Masons style each other brothers and brethren, and as certain religious societies call their members brethren, and say "Brother" so and so. They distinguish between the ruling brethren thus:- $¥$ Yih ko; Urh ko; San ko: i. e. "Brother first; Brother second ; Brother third." There may be others who take part in the management, where the society's members are numerous. The members generally are called $₫$ Heung $t \hat{e}$, i. e. "Brethren."

* See plate, No.8. $\quad+$ See plate, No.9. $\quad \ddagger$ See plate, No. 10. $\oint$ See plate, No. 11. 
Of the laws, discipline, and interior management of the San-hŏ-hwuy, the writer of this has not been able to obtain any information. There is said to be a MS. book, containing the society's regulations, written on cloth, for the sake of preserving the writing long in a legible state. Should a detection be made, the cloth MS. may, for the time, be thrown into a well or pond, from which it can afterwards at convenience be taken out; and in case of the person, in whose care it is, being pursued by the police, and obliged to swim across a river, \&c. he carries the MS. with him; and as the ink appears to possess a peculiar quality, the impression in either case is quite legible. As they cannot print their regulations, this seems well calculated to preserve them from oblivion.

The heads of this fraternity, as in all other similar associations, have a larger share of all the booty that is procured, than the other members.

\section{Fourthly, Initiatory Ceremonies.}

Of these but a very imperfect idea can be obtained. The initiation takes place commonly at night, in a very retired or secret chamber. There is an idol there, to which offerings are presented, and before which the oath of secresy is taken. The Chinese say there are ${ }^{*}$ San shih lŭh s'he, i. e. " thirty-six oaths" taken on the occasion; but it is probable that, instead of being distinct oaths, these are different particulars of one oath, very likely the imprecations contained in it, against persons who shall disclose the nature and objects of the society.

A small sum of money is given by the initiated to support the general expense. There is likewise a ceremony which they call $+K w_{0} K e a 0 u, i . e$. " crossing the bridge." This bridge is formed of swords, either laid between two tables (an end resting on each), or else set up on the hilts, and meeting at the point; or held up in the hands of two ranks of members, with the points meeting, in form of an arch. The persons who receive the oath, take it under this bridge, which is called-" passing, or crossing the bridge." The yih ko, or chief ruling brother, sits at the head of this steel bridge (or each with a drawn sword), reads the articles of the oath, to every one of which an affirmative response is given by the new member, after 
which he cuts off the head of a cock, which is the usual form of a Chinese oath, intimating-" thus let perish all who divulge the secret." But it is said the grand ceremony can only be performed where there is a considerable number of members present. They worship Heaven and Earth on those occasions, and sometimes, when the place is sufficiently secluded, perform the initiatory rites in the open air.

\section{Fifthly, Secret Signs.}

Some of the marks by which the members of the San ho hrouy make themselves known to each other, are those that follow:-Mystic numbers; the chief of which is the number three. They derive their preference for this probably from the name of their society, "the Triad Society." In conformity with this preference they adopt odd rather than even numbers, when it can be done. They say three, three times ten, three hundred, three thousand, three myriads, rather than two, four times ten, \&c.

The word *Hung, above-mentioned, contains the number three hundred and twenty-one, and is often used by them for particular purposes. They separate its component parts thus: †san-păh-urh-shih-yih. The character San is properly a form of $\ddagger$ shwuy (water), as used in composition, and should have this sound; but in the analysis of any Chinese character, of which this form of shrouy constitutes the dexter component, the teacher says to his pupil, $\$ san-teen shwuy, i.e. put " three points water at the side," or " the three point form of shrory." But when used by the san hr hwouy, the word san (or three) alone is employed; the other parts being out of place

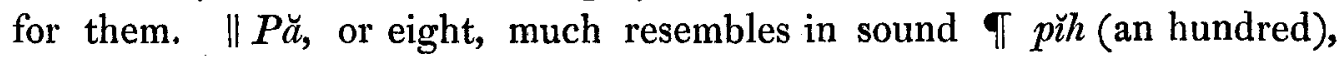
and in a rapid conversation is scarely distinguishable from it. ** Urh-shih is the united or mercantile form of t十 urh shŭh, or " two tens" run together for the sake of expedition in business. 㧊 $Y$ ih is the common form of one. Now hearing the component parts of Hung gone over in this manner, it seems to the uninitiated to mean $\$ \S$ san pih urh shih yih, " three hundred and twenty-one." What the members themselves mean by it, it is impossible

* See Plate I, No. 14. † See Plate I, No. 15. $\quad$ See Plate I, No. $16 . \quad \oint$ See Plate I, No. 17. II See Plate I, No. 18. I See Plate I, No. 19. * See Plate I, No. 20. t† See Plate I, No. 21 . 伯e Plate I, No. 22 . $\oint \delta$ See Plate I, No. 23. 
to discover. In zeriting, it is as above analyzed; or in uttering the sound of the components, they equally understand each other's meaning.

Certain motions of the fingers constitute a second class of signs; e.g. using three of the fingers in taking up any thing. If a member happens to be in company, and wishes to discover whether there be a brother present, he takes up his tea-cup or its cover (Chinese tea-cups have always a cover), with the thumb, the fore, and middle fingers, or with the fore, middle, and third fingers, and which, if perceived by an initiated person, is answered by a corresponding sign. It does not, however, follow from this that every Chinese who uses three fingers, in taking up, or holding, his tea-cup, is a member of the san ho hrouy, for many of them do it from mere habit. But there is a certain roay of doing it by the initiated, which they themselves only know. In lifting any thing that requires both hands, they use three fingers of each hand.

They also have recourse to odes and pieces of poetry, as secret marks.(See below, under Particular 6th, "Explanation of Characters within the first Octangular lines.)

\section{Sixth, the Seal.}

The seal is a quinquangular figure : this, as above noticed, is one of the Society's mystical numbers. From the manner in which some characters on the seal were written, it is not improbable that some of them have been erroneously explained. The following is submitted as the best explanation of them which the writer's present circumstances enable him to furnish.*

Explanation of the Characters at the five corners, in the outer, or quinquangular lines.

1. Tóo, the earth planet, i.e. Saturn; which, according to the Chinese, especially regards and influences the centre of the earth; also one of the five elements.

2. Mŭh, the wood planet, i.e. Jupiter, or that planet which reigns in the eastern part of the heavens.

* For an engraving of the seal, see Plate II, No. 1. 
3. Shrouy, the water planet, i.e. Mercury, to which the dominion of the northern hemisphere is confided.

4. Kin, the metal planet, i.e. Venus, to which the care of the west is confided.

5. Ho, the fire planet, i.e. Mars, to which the southern hemisphere is assigned.

N.B. The reasons (or some of the reasons) why these planets are placed at the corners of this seal, may be, because they are the basis of Chinese astrological science, and because they are considered the extreme points of all created things.

Explanation of the five Characters which are directly under the Planets.

6. Hung, a flood or deluge of waters. One of the secret designations of this fraternity is Hung kea, literally, "the flood family ;" intended, perhaps, to intimate the extent and effectiveness of their operations, that, as a flood, they spread and carry every thing before them.

7. Haou, a leader; a chief or brave man.

8. Han, the name of an ancient dynasty; but, in certain connections, signifying a bold and daring man, which is most probably the sense here.

9. Ying, a hero.

10. Kea, a stand; but metaphorically used to denote a person of importance to the state, or to society, as we use tropes, and say, "such man is a pillar," "the stay of his country."

$N . B$. Though this be the ordinary meaning of these words, it is possible that they may be used by the fraternity in a mystical and occult sense.

Explanation of the other Characters within the same lines.

$11,12,13,14,15,16,17$. Ying, heung, hwuy, ho, twan, yuen, she.

18, 19, 20, 21, 22, 23, 24. Heung, te, fun, kae, yih, show, she.

"The hero band in full assembly meet;

" Each man a verse, to make the ode complete."

This is a very probable sense of the words as they are placed, especially as it is known to be a frequent practice of this fraternity to converse together in poetry; and in order to elude suspicion while in company with others, 
one man takes but a line, or half a line, which by itself is utterly unintelligible to persons not initiated, but which, being understood by a brother member, is responded to by him in another line or half a line, and, by thus passing on through several persons, an ode may be completed, though not perceived by any but the parties themselves.

25, 26, 27. Kёe te tuy. These three words are inexplicable in the order in which they stand. Kěe signifies to tie, to bind, and often used to signify the formation of a secret association. Te (if we be right in the character) signifies a brother, or younger brother, and the sense thus far would be" to form a brotherhood." Tuy, is a pair of any thing, or two things equal to each other. But it is probable that these words have a reference to other words on the seal, the connection of which seems difficult to discover.

Explanation of Words within the first octangular lines.

28, 29, 30, 31. Heüng te tung chin,

32, 33, 34, 35. Kó yeu haou tow ;

36, 37, 38, 39. Kaou k'e fun pae ;

40, 41, 42, 43. Wan koo yeu chuen.

Which may be thus rendered :-

The Brethren all in battle join,

Each ready with a chosen sign;

An ancient brook with parting streams,

Still flowing down from long-past times.

In support of this version it might be urged, that the fraternity have certain secret signs or marks, by which they make their ideas known to each other, and in the tumult which they excite, these signs are made use of to encourage each other in the work of destruction; and that they consider their society as of very ancient origin, and as spreading through the world from age to age.

But the words may be read in lines of eight or seven syllables, and might begin at the 32d, thus :-

Kŏ yew haou tów kaou k'e fún,

Kaou ke fun pae wan koo yew.

N.B. This last line shifts back to 36 for its first syllable. 
In fact, there appears scarcely to be a limit to the mutations of these numbers; for, like the changes of the pă $k w a$ (Chinese table of diagrams), they may contain an infinitude of senses and modifications, with which, however, the initiated alone are familiar.

Explanation of Characters within the second octangular lines.

$44,45,46,47,48,49,50$. These characters, as they stand, seem to make no intelligible sense, and from the circumstance of their being written with two kinds of ink, black and red, renders it highly probable that they are constructed for the purpose of local concealment; they are perhaps the names, real or assumed, of the officers of the brotherhood; that half of the characters in red ink, which seems printed, may be permanent, and have some general reference to the designs of the society, and to the other characters on the seal; while the yellow part (on the original blue silk seal), which is evidently written with a pencil, may, joined to the printed half, constitute the names or epithets of the officers in some particular place. In another place, where persons of different designations are chosen to be officers, the yellow part would be different. This conjecture is confirmed by the opinion of several learned Chinese, who have seen and examined the seal.

$51,52,53,54$. These characters have, no doubt, a reference to the ultimate view of the brotherhood, viz. universal extension and dominion. 51 is an inverted form of 53 ; and 53 is an abbreviated form of *wan, a myriad. 52 (in the quinquangular lines) signifies "Heaven," and 54, "Earth." And the position of 54 and 53, both looking towards the straight line on which the words "Heaven" and "Earth" are written, may mystically signify the bringing of myriads of nations under the society's influence

Explanation of Characters within the square lines.

55, 56, 57, 58, 59, 60. Chung e foo, wo chŭh tung, i.e. " Let the faithful and righteous unite so as to form a whole" (i.e. an universal empire). This seems the plain sense of the words, according to this arrangement of them; 
but it is impossible to ascertain whether something else may not be intended, as they are susceptible of as many meanings as arrangements. This version, however, agrees with the general views of this dangerous fraternity.

\section{Characters within the oblong square.}

61, 62. Yun shing; supposed to be the name of the chief of the fraternity, some think the founder, but, the character being roritten, and in yellow ink, it is more likely to be the chief for the time being, at whose death the blank space in seals subsequently issued could be filled up with the name of his successors; whereas the name of the founder, never changing, would be more likely to be printed, in some permanent form.

\section{MISCELLANEOUS REMARKS.}

If any weight be due to the scattered hints that have been given above, there will appear to be a striking resemblance in some points between the San ho hwuy, and the Society of Free-Masons. The writer would not be understood, by so saying, to trace this resemblance in any of the dangerous principles of the San ho hwuy, for he believes that the Society of British Free-masons (and of others he knows nothing) constitutes a highly respectable body of men, whose principles and conduct are friendly to social order, regular government, and the peace of society. The points of resemblance, then, between the two societies, appear to the writer to be the following :-

1. In their pretensions to great antiquity, the San ho hwuy profess to carry their origin back to the remotest antiquity. * Tsze yeu chung Kwo, i. e. "from the first settlement of China;" and their former name, viz."Colesto-terrestrial Society," may indicate that the body took its rise from the creation of heaven and earth; and it is known that some Free-masons affirm that their society "had a being ever since symmetry and harmony began," though others are more moderate in their pretensions to antiquity. 
2. In making benevolence and mutual assistance their professed object, and in affording mutual assistance to each other, in whatever country, when the signs are once given. Notwithstanding the dangerous nature of the San hb hwouy, the members swear, at their initiation, to be filial and fraternal and benevolent, which corresponds to the engagement of the Free-masons, to philanthropy and the social virtues.

3. In the ceremonies of initiation, $e . g$. the oath, and the solemnity of its administration, in the arch of steel and bridge of swords. These are so singularly striking, that they merit the attention of those especially who think Free-masonry a beneficial institution, or who deem its history worthy of investigation.

4. May not the three ruling brethren of the San ho hrouy be considered as having a resemblance to the three masonic orders of apprentice, fellowcraft, and master?

5. The signs, particularly " the motions with the fingers," in as far as they are known or conjectured, seem to have some resemblance.

6. Some have affirmed that the grand secret of Free-masonry consists in the words "Liberty and Equality ;" and if so, certainly the term "Heung Te, (i.e. "brethren") of the San ho hwuy may, without the least force, be explained as implying exactly the same ideas.

Whether there exist any thing in the shape of "Lodges" in the San ho hwouy, or not, the writer has no means of ascertaining; but he believes the Chinese law is so rigorous against this body, as to admit of none.t Nor does there appear to be a partiality among the members for the masonic employment. Building does not appear to be an object with them, at least not in as far as can be discovered.

* See Plate II, No. 4.

+ To belong to this Society is, in China, a capital crime.

The late Dr. Milne sent these notices of this Triad Society to China, for further investigation, in July, 1821, and died on the $2 \mathrm{~d}$ of June, 1822 : and hence the paper was left in its present unfinished state.-Note by Dr. Morrison. 